\title{
What Does the Future Hold for The Canadian Wheat Board? Trade Friction, Dispute Settlement and State Support for Agriculture in North America
}

\author{
Marc D. Froese \\ Department of History and Political Science \\ Canadian University College
}

\begin{abstract}
$\underline{\text { Abstract }}$
This paper examines the substance of the WTO panel decision for Canada-Wheat as it relates to the ongoing debate about the future of the Canadian Wheat Board. In this case, the WTO upheld the legality of Canada's marketing board for wheat and barley. The decision suggests that trade discipline may play less of a role in Canada's ongoing adjustment processes than other factors such as proximity to American markets and other competitive pressures that result from exposure to global markets. Furthermore, in aggregate terms, Canada and the US have been adjusting levels of support downwards over the past decade. What then is the future of the CWB? Dismantling the CWB may fit Canada's long-term industrial development pattern. However, in the immediate future the federal government must carefully consider the implications of removing programs that provide security for domestic producers - especially in light of aggressively protectionist sentiment in the American agriculture sector.
\end{abstract}


Agriculture is one of Canada's leading value-added industries (Cross, 2007). Like all agricultural exporters, Canada has a number of programs in place to deal with volatility in global markets for agricultural products. Wheat prices in particular are somewhat cyclical and have a higher variable of growth compared to the total Canadian business sector. In Canada, market volatility has been managed through wheat pooling and the international sale of wheat through a single desk marketing system. In the United States, price swings are managed by direct payments to exporters through the US Department of Agriculture's Foreign Agriculture Service. The Canadian Wheat Board (CWB) is part of a historically rooted trajectory of national industrial development (Zysman, 1996). Like American farm support programs, it plays an important political role in stabilizing the agricultural sector alongside its commercial function of maximizing wheat sales for farmers.

Since coming to power in 2006, the Federal Conservatives led by Prime Minister Stephen Harper have made it a key policy aim to dismantle the Wheat Board (Conservative Party of Canada, 2006). The main issues for opponents of single desk marketing in Canada are political only Western Canadian farmers must sell to the CWB. Farmers in other parts of Canada have separate marketing boards and participation is voluntary. There is also evidence that the current system forces farmers and tax payers to bear hidden costs; it is these costs, coupled with a lack of marketing choice that Western farmers take issue with (Carter and Loyns, 1996). The proponents of the CWB argue that farmers are protected to a certain degree from market volatility and the Canadian Wheat Board brand is known globally for its high-quality product. The main issue for American competitors is structural. There is a perception in the American wheat industry that the Canadian Wheat Board is structured in such a way as to ensure it will not operate in accordance with commercial considerations - that is, in the interests of free market competition.

This paper examines the substance of the WTO panel decision for Canada-Wheat as it relates to the ongoing debate about the future of the CWB. Canada-Wheat was the first WTO panel to consider the substance of Canada's marketing model for Western Canadian wheat and barley. It was also the first test of the WTO's regulation of STEs under GATT Article XVII (Hoekman and Trachtman, 2007). The first section contains an overview of the place of state trading enterprises in international trade and examines the cases for and against this form of producer support. It then examines the impact of the CWB on Canada/US trade relations in greater detail, arguing that the trade friction caused by Canada's single marketing board for Western Canadian wheat and barley is not caused by the trade distorting impact of the CWB as much as it is a product of long term competitive pressures in the North American market for wheat.

The second portion of this paper examines the WTO Panel and Appellate Body reports in the 2004 Canada-Wheat case. The WTO panel found that the primary discipline of GATT 
Article XVII:1 governing STEs was non-discrimination, and operating on the basis of 'commercial' considerations, as commerce was defined in the American argument, was not an independent obligation (Hoekman and Trachtman, 2007). Canadian structural adjustment is usually explained by a number of factors, the most important being American political pressure and international trade agreements (Clarkson, 2001). In this case, the WTO upheld the legality of Canada's state trading enterprise, suggesting that trade discipline may play less of a role in Canada's structural adjustment process than other factors such as proximity to American markets and other competitive pressures that result from increased exposure to global markets.

The final section remarks upon the convergence of Canadian and American levels of support for agriculture (OECD 2007). Both countries are adjusting levels of support downwards overall, and each country responds to the pressures of intrasectoral competition in different ways. What then is the future of the CWB? Are its days numbered? Dismantling the CWB may fit Canada's long-term industrial development pattern. However, in the immediate future the federal government must carefully consider the implications of removing programs that provide security for domestic producers - especially because of aggressively protectionist sentiment in the American agriculture sector. Furthermore, competition issues are not on the table in the Doha round and a panel has ruled upon the basic legality of the CWB. Political pressure from a trade competitor should not influence decisions made about a well-established and particularly successful model for marketing and selling Canadian wheat.

\section{Trade Friction in the North American Market for Wheat}

A number of kinds of STEs trade in agriculture markets - statutory marketing boards, canalising agencies, and foreign trade enterprises are operated by the vast majority countries that export agricultural goods. The CWB is a marketing board and the last two organizational frames are often used by developing countries to develop markets of scale for trade operations. There is a small body of literature that examines the role of STEs in global agriculture markets. Much of the literature assumes that STE market power stems from their special privileges and relationship with national govts, and that they compete in otherwise perfectly competitive markets.

Recent studies have shown that this is a problematic assumption (Abbott and Kallio (1996), Pick and Carter (1994), and Veeman et al (1999). Much of the world grain trade controlled by five multinationals - including Cargill and Louis Dreyfus, international grain traders frequently 'price to market.' A handful of multinational companies have a large influence on world wheat prices. Canadian Wheat Board sales totalled approximately 2.2 billion in 2003.In comparison, Cargill sales topped $\$ 60$ billion and the Louis Dreyfus Group posted sales worth $\$ 20$ billion (CWB, 2005). Canada's single desk marketing system is a small player in a very big industry, one that does not meet the standard definition of free market competition.

Since 1995 the US has been especially keen to curtail the activities of agricultural state trading enterprises or ban them altogether (OECD 2001). There is a perception on the part of the American wheat industry that state trading enterprises enjoy levels of governmental support that far outstrip the support enjoyed by American farmers. Indeed, in 1995 Canadian wheat transportation legislation was significantly changed to bring it into line with WTO law. Similarly, American farm support has been retooled over the past decade as well, although the 
American model of agricultural support still relies almost exclusively on cash payments to farmers. The USDA's Export Enhancement Program, which was developed under the rationale that US agricultural exporters needed government support to compete with Europe's heavily subsidized agriculture sector, has been slowly phased out, replaced by other industry specific export subsidies such as the Dairy Export Incentive Program and the Market Access Program.

The Canadian Wheat Board was established by parliament in 1935, and still retains its headquarters in Winnipeg, the traditional gateway to the West. It is governed by a fifteen person board of directors, ten of whom are elected farmers, four are appointed by federal minister of agriculture, and the president of the board is appointed by prime minister (CWB, 2005). The CWB acts as a marketing agent for all western Canadian wheat and barley farmers. It pays out an interim payment for crop and a final payment - the amounts of which are set by the current year's sales volumes and prices. This pooled selling system ensures predictable cash flow for farmers through pooled prices and a government price guarantee if marketing forecasts fall below expectations. Notably, in the case of wheat and malt barley, it does not allow individual farmers to choose where, when and to whom to market their product. In all other products farmers are not subject to the marketing control of the Canadian Wheat Board.

High levels of farm support are as old as the trade regime itself. In fact, the most glaring compromises made by the original GATT signatories with the post-war economic order were in agriculture. The North American agricultural trade environment today is the result of diverse economic policy choices made by member governments in the process of navigating the postwar trading system. Many of these policy choices were made between 1930 and 1960, and involved what Ruggie (1982) terms a compromise with embedded liberalism. The balance developed by G7 nations during this formative period allowed them to manage the social adjustment costs of increased market openness. ${ }^{1}$

These different approaches to managing volatile business cycles survived and flourished in the post-war international economic order. Embedded liberalism, as a theoretical tool to analyze different national regulatory approaches to post-war integration, has lost some of its currency. Keohane (1984) successfully argued that America's move away from the gold standard ended American economic hegemony and marked the end of post-war embedded liberalism. Markets are now global and the distinction between national and international business transactions has lost some of its significance. Nevertheless, trade friction that still arises from different public policy strategies that are rooted in historical compromises with embedded liberalism.

Trade friction in the North American agriculture sector occurs when competitors perceive an incompatibility in approaches to regulation that gives one an unfair advantage over the other. This can be a measurable obstacle to trade such as legislation that violates a trade agreement, but it can also be the perception or suspicion of market distorting practice, such as the long-standing belief that Canadian stumpage fees constitute a form of softwood industry subsidization (Gagne, 2003). This is also what occurred in the Canada-Wheat case. American regulators have long harboured the suspicion that Canada's centralized marketing board for wheat and barley distorts

\footnotetext{
${ }^{1}$ Much of the agricultural legislation in the US dates from the 1930s and of course Canada's wheat board dates from 1935.
} 
open markets by giving the Canadian Wheat Board monopsony powers at home to buy Western Canadian wheat and monopoly powers abroad sell it on the international market (Petersmann, 1998). In the North American context, friction between support mechanisms has been a prominent trade irritant. Yet the wheat case is not a debate over economic outcomes per se. Rather, it is a continuation of the old twentieth century debate over the proper role for government in the economy.

\subsection{Trade in Agricultural Goods and State Trading Enterprises}

Prior to the Uruguay Round Final Act, the GATT placed fewer restrictions on agriculture than it did on other sectors. According to Trebilicock and Howse (1999), a number of major states came close to ignoring GATT altogether, even refusing to implement GATT panel decisions. Special treatment in agriculture was largely a reflection of the influence of the United States after the Second World War (ibid). Import quotas and export subsidies were an essential part of the American supply management framework for agricultural products.

GATT regulation of trade in agriculture is concerned chiefly with quantitative restrictions and export subsidies. Article XI bans quantitative restrictions on imports, with some significant exceptions - relevant ones include exceptions in order to address critical food shortages such as export restrictions and restrictions for the application of standards and regulation. Export subsidies are also prohibited except in the case of primary products' defined as any product of farm, forest or fishery at an early stage of processing (GATT 1947). And in the case of primary products, export subsidies cannot be used to increase a nation's share of international trade. Domestic subsidies and domestic support measures also fall under the GATT's oversight, but are much more difficult to police.

GATT Article XVII deals with the regulation of state trading enterprises. The substantive obligations of members under the rules governing state trading are: non-discrimination (MFN treatment), no quantitative restrictions, preservation of the value of tariff concessions (no price domestic price manipulation), and transparency (WTO, 2007). In defining non-discriminatory treatment, strict MFN treatment is not necessarily required (GATT, 1994). This allows a state trading enterprise to charge different prices for its products in different markets, provided that this is done for commercial reasons, that is, to meet supply and demand conditions in export markets. $^{2}$

According to WTO notifications, STEs serve a number of purposes - income support, price stabilization, increase in govt revenue, protection of public health, continuity of domestic food supply. ${ }^{3}$ Trebilcock and Howse (1999) add that STEs are also linked to arguments having to do with self-sufficiency and national security and preservation of the environment and the

\footnotetext{
${ }^{2}$ Two other articles are pertinent to this discussion. Article XX (d) covers general exceptions and subparagraph (d) states that states that nothing in the Agreement "shall prevent the adoption or enforcement by any member of measures necessary for ensuring compliance with regulations relating to the enforcement of monopolies." Article XXXVII:3 (a) deals with places where government determines the resale price of products produced in developing countries, members should maintain trade margins at equitable levels.

${ }^{3}$ As of October 2007, 71 out of 151 members had notified the WTO that they are now, or have in the past seven years operated a state trading enterprise. The number of members operating STEs is likely to be much higher given the notoriously low reporting rate. Access to annual reports of the WTO’s Working Party on State Trading Enterprises is available through the WTO website at http://www.wto.org/english/tratop_e/statra_e/statra_e.htm.
} 
rural way of life. Income redistribution is often the primary reason for the use of STEs. In addition to exploiting national market power by aggregating the supplies of many farmers, STEs can act to distribute income towards or away from farmers. In the Canadian case, the CWB acted to distribute income towards farmers. But in developing countries, governments frequently use STEs to transfer resources to consumers of food. (Hoekman and Trachtman, 2007 p. 8)

GATT recognizes STEs as legitimate participants in trade but but also recognizes that they have the potential to distort trade if they make decisions based on government instruction rather than market principles. It is difficult to quantify the anticompetitive effects of export STEs because they do not directly subsidize their exports to world markets. However, because the STE is in place in lieu of a subsidy there is a continually abiding suspicion that their behaviour does not always correspond to that of other private actors and ties to national governments give them unfair advantages vis-a-vis private competitors. Trachtman and Hoekman (2007, p. 4) give five ways that STEs can be used to circumvent WTO commitments. First, they can circumvent the MFN principle enshrined in GATT Article I by discriminating among trade partners regarding purchases and sales. Second, they can circumvent the National Treatment principle of GATT Article III by discriminating among domestic and imported goods (Canada lost on this point in its treatment of foreign wheat at Canadian elevators). Third, if they have import privileges, they can restrict quantities of imports contra GATT article XI. Fourth, they might exercise import rights to sell imported goods at mark-ups that operate like tariffs. Finally, STEs may use their purchases and sales to subsidize sellers and buyers. ${ }^{4}$

A main concern of the US was that the CWB was using its market power and discriminatory pricing behaviour as a de facto subsidization mechanism for Western Canadian wheat producers by discriminating between foreign and domestic product behind the border. There was a concern that implicit subsidization was occurring in the economic sense, if not in the legal sense. US sought a finding of broad discipline on the competitive behaviour of STEs (Hoekman and Trachtman, 2007 p. 11). A case based on this sort of large and sweeping indictment had a certain amount of traction because the CWB does not necessarily maximize export profits, as a private economic actor does; rather it uses its market power to get the best prices for its different products in many different national markets. ${ }^{5}$

\section{Canada - Measures Relating to Exports of Wheat and Treatment of Imported Grain}

Over the past two decades, the American wheat industry has brought more than a dozen challenges against Canada's centralized system for buying and selling wheat (See Annex for a complete list of these cases). Beginning in the early 1990s, the US International Trade

\footnotetext{
${ }^{4}$ OECD research has shown that economists need to differentiate between the monopoly aspect of an STE and its objective function. The assumption is frequently made that STEs will act like private firms in a monopoly position. However, "the public nature of the state trading enterprise distinguishes it from a private firm. . . although a state trading enterprise may hold a monopoly position, it may not behave in a traditional textbook manner” (OECD 2001, p. 54).

${ }^{5}$ The CWB exploits quality differences in wheat grades in order to leverage higher prices across many national markets. However, its ultimate goal is to sell as much wheat as possible, rather than to sell wheat at the highest possible price. Nevertheless, Canadian wheat commands High prices that are a reflection of the high quality of the Canadian product.
} 
Commission investigated charges of Canadian wheat being dumped on the American market. In 1993 a case was taken by US regulators to the new dispute settlement process in the Canada-US Free Trade Agreement, and Canada won. Five more challenges were launched by the ITC, Department of Commerce, and Government Accountability Office throughout the 1990s. Canadian wheat exports to the US were briefly capped in 1994 and 1995 . Between 2003 and 2005 duties were twice imposed on Canadian wheat by the Department of Commerce. In both cases the finding of material injury was appealed at NAFTA and subsequently reversed. And then came the most serious charge - a full court press at the WTO to find the Canadian Wheat Board and a number of other support mechanisms in contravention of Canada's MFN obligations and GATT Article XVII:1, which defines the limits of state trading.

Canada-Wheat concerns two aspects of Canada's regulatory apparatus for the transport and sale of wheat. These form to significant portions of what Furtan (2000) has termed Canada's "national policy" concerning wheat from the prairies. The first part of the American challenge concerned Canada's export regime for wheat, the Canadian Wheat Board. It included the legal framework of the CWB, its special rights and privileges granted by the Federal government and its actions with respect to wheat purchasing at home and sales abroad of Canadian wheat.

The second part concerned requirements contained in the Canada Grain Act (CGA), the Canada Grain Regulations and the Canada Transportation Act, for the treatment of grain imported into Canada. Section 57c of the CGA governs the receipt of foreign grain into Canadian elevators. Section 56(1) of the Canada Grain Regulations disallowed the mixing of certain types of foreign and domestic grain in Canadian elevators. Section 150 of the Canada Transportation Act imposed a cap on revenues earned by certain railways for the transportation of Western Canadian grain. Finally, section 87 of the CGA allows producers to apply for a railway car to transport their wheat to a grain elevator or a cosignee.

Together, these measures add up to a policy that protects Canadian wheat producers from the vagaries of the international market and from significantly increased transportation costs caused by seasonal demand for railway transportation. The American case claimed that these were also trade distorting measures that gave Canadian wheat producers an unlawful set of trading advantages, both in terms of sale on the international market as well as in terms of the treatment of treatment of grain at home, vis-a-vis imported wheat.

\subsection{The Panel Report}

The American claim under GATT Article XVII :1 that the Canadian Wheat Board breached Canada's obligations was a challenge to the entire CWB export regime (paragraphs 6.18-21, 6.24-25). The American suit alleged that illegality of the CWB export regime proceeded from a combination of three elements - the CWB's legal structure and mandate, its privileges and the incentives that flowed from those privileges, and the lack of supervision by the Canadian government. In particular, the US made three claims:

1. The CWB Export Regime is not consistent with GATT Article XVII:1;

2. Canadian grain segregation requirements in Section 56 of the Canada Grain Regulations and Section 57 of the Canada Grain Act are inconsistent with GATT Article III:4 (national treatment) and TRIMS Agreement Article 2 (investment); and 
3. The rail revenue cap and the producer railway car program were also inconsistent with the national treatment principle enshrined in Article III of the GATT and Article 2 of Trade Related Investment Measures Agreement. ${ }^{6}$

Before examining this claim, the panel addressed disagreement over the meaning of the terms of Article XVII:1 (a) and 1 (b):

1. (a) Each contracting party undertakes that if it establishes or maintains a State enterprise, wherever located, or grants to any enterprise, formally or in effect, exclusive or special privileges, such enterprise shall, in its purchases or sales involving either imports or exports, act in a manner consistent with the general principles of nondiscriminatory treatment prescribed in this Agreement for governmental measures affecting imports or exports by private traders.

(b) The provisions of subparagraph (a) of this paragraph shall be understood to require that such enterprises shall, having due regard to the other provisions of this Agreement, make any such purchases or sales solely in accordance with commercial considerations, including price, quality, availability, marketability, transportation and other conditions of purchase or sale, and shall afford the enterprises of the other contracting parties adequate opportunity, in accordance with customary business practice, to compete for participation in such purchases or sales (GATT 1947).

The panel noted that Canada and the US disagreed over whether the provisions of paragraphs 1(a) and 1(b) form an obligation on the part of members to ensure that their STEs comply with certain standards or whether, as Canada argued, the provisions only require that STEs act in such a way that a member is responsible for their actions under international law, but if a complaining party is unable to demonstrate that the STE in question is not meeting its legal obligation, then "that Member must be assumed to have honoured its undertaking." (paragraphs 6.34-36, 6.40)

The panel examined three interpretive issues surrounding XVII:1(b) - the most important being the interpretation of the first clause of subparagraph (b) that states that "such enterprises shall, having due regard to the other provisions of this Agreement, make any such purchases or sales solely in accordance with commercial considerations" (emphasis added). The panel did not accept the US argument that STEs must act like "commercial actors" that "maximize profit[and] do not enjoy government-conferred privileges and are disciplined by market forces." (paragraphs 6.84-88) In the panel's opinion the clause simply meant that STEs must make decisions based upon commercial, rather than political considerations. STEs "should seek to purchase or sell on terms that are economically advantageous for themselves, and/or their owners, members, beneficiaries, etc" (ibid). In short, the panel determined that although a state trading enterprise may be granted rights and privileges that have a political goal, such as support for farmers, it must operate based on commercial considerations. For example, an STE would not be acting on

\footnotetext{
${ }^{6}$ For a full case commentary see "Dispute Settlement Commentary - Wt/Ds276/R." In Worldtradelaw.net Dispute Settlement Commentary. Wellington, FL: Worldtradelaw.net LLC, 2004.
} 
commercial considerations if it buys or sells on the basis nationality of the buyer or national interest of its member government.

The US claim that the CWB Export Regime "necessarily results” in non-conforming sales was based on four broad assertions:

1. Privileges enjoyed by the CWB give it more flexibility than would be enjoyed by a commercial actor;

2. Pricing flexibility allows the CWB to offer 'non-commercial' sales terms thereby 'commercial' enterprises of an opportunity to compete;

3. The CWB's mandate and legal structure create an incentive for it to maximize sales rather than profits, meaning that it can discriminate between markets, selling lower in some markets for example. In this way the CWB encourages the overproduction of highquality grain; and

4. The Government of Canada does not ensure that the CWB conforms to Article XVII:1 (a) and (b) and in the absence of government safeguards the CWB's legal structure and mandate result in non-conforming sales of wheat.

The panel decided that these assertions must be taken together in order to demonstrate non-conforming sales, and so the US had to establish the veracity of all four assertions. It proceeded to examine the first part of the American challenge - that the CWB's legal structure gives it an incentive to make sales that do not conform to its obligations under GATT Article XVII:1. The panel disagreed, noting that the majority of directors that serve on the CWB are elected by Canadian wheat and barley producers. These directors ensure returns for producers by maximizing sales. It also noted that the CWB Act requires directors and officers to "act honestly and in good faith with a view to the best interests of the [CWB]." (paragraphs 6.123-134) The CWB's legal structure does not give it an incentive to make wheat sales on a basis other than commercial considerations.

The panel also rejected the US assertion that the CWB's mandate to strive for a 'reasonable price' meant that the CWB did not strive for a profit-maximizing price. The panel decided that although the CWB was not striving to make a profit for itself, it was attempting to maximize the returns for its producers. Further, Article XVII:1 does not suggest that STEs only meet the 'commercial considerations' requirement if operations are structured to maximize profit. They can also be structured to meet other goals that benefit its producers, such as the maximization of returns. The panel concluded that "(a) the United States has not established that the CWB Export Regime necessarily results in non-conforming CWB export sales; and, as a consequence (b) the United States has not established that Canada has breached its obligations under Article XVII:1 of the GATT 1994.” (paragraph 6.151)

It moved on to examine the other charges brought against Canada's wheat export regime. Section 57(c) of the CGA does not allow elevators to receive foreign grain except when authorized by regulation or the Canada Grain Commission. Panel found that the section is inconsistent with GATT Article III:4 because imported grain is treated less favourably than domestic grain because an additional regulatory burden must be met by foreign grain before it can enter Canada’s grain handling system. 
Turning next to an examination of the consistency of Section 57(c) of the Canada Grain Act (Receipt of Foreign Grain) with GATT Article XX (d), Canada's defence of its differential treatment of foreign grain in its domestic grain handling system involved the general exceptions clause of GATT. Canada argued that Section 57(c) necessary to ensure compliance with wheat grading requirements and to make sure that foreign wheat is not misrepresented as domestic wheat in Canada and elsewhere. The panel found that Canada could put policies into place that would do the same things it was intending to do without placing an extra regulatory burden on foreign wheat and therefore Section 57(c) of the Canada Grain Act was not justified under GATT Article XX(d).

Likewise, Section 56(1) of the Canada Grain Regulations allows the mixing of any grade of grain coming into or going out of an elevator as long as neither is western grain or foreign grain. The US argued this is a discrimination in contravention of GATT Article III:4 because it is based on place of origin, not on whether the products are 'like products.' Panel also found that the section was inconsistent with GATT. Canada made the same GATT Art XX(d) defence and panel struck it down for same reasons.

In the examination of the consistency of Sections 150(1) and 150(2) of the Canada Transportation Act (Rail Revenue Cap) with GATT Article III:4, the US argued that "the effect of these provisions taken together is that domestic grain is favoured over like imported grain" in that there is an incentive for railways to hold prices down for Western Canadian grain, but no incentive exists for the transportation of foreign grain. (paragraph 6.328) Canada responded that "the revenue cap has never been met and is unlikely to be met in the future" and therefore no adverse trade effects have ever been felt by foreign grain. (paragraphs 6.357-358) The Panel emphasized that it is not necessary to demonstrate adverse trade effects because Article III protects the conditions of competition, and struck down the rail revenue cap.

The panel ruled in Canada's favour in the final two allegations brought by the US. Section 87 of the Canada Grain Act allows producers of grain who meet certain conditions to apply for a railway car to take their grain to an elevator. The US argued that this mechanism was discriminatory because it only allowed domestic producers to access the railway car program. The panel disagreed, ruling that there was nothing in the statute that limited access to railway cars to domestic producers. Finally, the US claimed that Section 87 of the Canada Grain Act is inconsistent with TRIMS Article 2 because it "requires shippers to use domestic Canadian grain in order to obtain an advantage. Recalling its finding above, the panel ruled that because the US had not established that Section 87 excluded foreign producers nor that section 87 was necessarily inconsistent with TRIMS Article 2.1. 


\section{Table 1: Anatomy of the Panel Decision}

Examination of the legality of Canada's export regime for wheat

- $\quad$ The CWB's legal structure does not give it an incentive to make wheat sales on a basis other than commercial considerations. The panel also rejected the US assertion that the CWB's mandate to strive for a 'reasonable price' meant that the CWB did not strive for a profit-maximizing price. The panel decided that although the CWB was not striving to make a profit for itself, it was attempting to maximize the returns for its producers. Further, Article XVII:1 does not suggest that STEs only meet the 'commercial considerations' requirement if operations are structured to maximize profit. They can also be structured to meet other goals that benefit its producers, such as the maximization of returns.

Examination of the consistency of Section 57(c) of the Canada Grain Act (Receipt of Foreign Grain) with GATT Article III:4

- $\quad$ The panel found that the section was inconsistent because imported grain was treated less favourably than domestic grain

Examination of the consistency of Section 57(c) of the Canada Grain Act (Receipt of Foreign Grain) with GATT Article XX (d)

- $\quad$ The panel found that Canada could put policies into place that would do the same things it was intending to do without placing an extra regulatory burden on foreign wheat and therefore Section 57(c) of the Canada Grain Act was not justified under GATT Article XX(d)

Examination of the consistency of Section56(1) of the Canada Grain Regulations (Mixing Authorization) with GATT Article III:4

- $\quad$ The panel found that the section was inconsistent with GATT.

Examination of the consistency of Section 56(1) of the Canada Grain Regulations (Mixing Authorization) with GATT Article XX(d)

- $\quad$ The panel found that the section was inconsistent with GATT.

Examination of the consistency of Sections 150(1) and 150(2) of the Canada Transportation Act (Rail Revenue Cap) with GATT Article III:4

- $\quad$ The panel struck down the rail revenue cap.

Examination of the consistency of Section 87 of the Canada Grain Act (Producer Railway Cars) with GATT Article III:4

- $\quad$ The panel ruled that there was nothing in the statute that limited access to railway cars to domestic producers and therefore Section 87 of the CGA was consistent with GATT.

Examination of the consistency of Section 87 of the Canada Grain Act (Producer Railway Cars) with TRIMS Agreement Article 2

- $\quad$ The panel ruled that because the US had not established that Section 87 excluded foreign producers nor that section 87 was necessarily inconsistent with TRIMS Article 2.1 


\subsection{The Appellate Body Report}

The dispute settlement panel in the wheat case took the view that the term 'commercial' simply refers to economic action that is actually taking place in the marketplace. The US had sought to define the term commercial as referring to an undistorted free market. The panel decided that the term, although it referred to business interaction within the market did not preclude goals other than profit (Trachtman and Hoekman, 2007 p. 30). The Appellate Body report clarified the relationship between subparagraphs (a) and (b) of Article XVII:1. Subparagraph (a) "sets out an obligation of non-discrimination" and subparagraph (b) "clarifies the scope of that obligation." (paragraph 100) It disagreed with the US interpretation that subparagraph (b) "establishes separate requirements that are independent of subparagraph (a)." (paragraph 100) The significance of this clarification is that it more fully defined the scope of Article XVII:1. The American definition of 'commercial' in subparagraph (b) would have established a separate obligation for Members and their STEs and would have narrowed the proper scope of STE activity significantly. Any STE that could not prove that its actions were only in the service of profit-maximization and undistorted market competition would have been in contravention of GATT.

The Appellate Body's definition of the relationship between subparagraphs (a) and (b) is narrower. It does not allow for the expansion of obligations under subparagraph (b) but rather argues that the text provides illustrative examples of discrimination that is prohibited in (a). This interpretation of Article XVII:1 preserved a significant realm of autonomy and scope of action for STEs. This is significant in the Canadian context because the panel ruled that the CWB's approach to grain exports that maximizes sales for farmers rather than profits from individual transactions is a perfectly legitimate way for an STE to conduct business in the global marketplace.

The Appellate Body adopted an interpretation of Article XVII:1 that limits its disciplines to non-discrimination. STE action need not conform to free-market expectations it must only be non-discriminatory. It declined to find a requirement that STEs act like private actors and in this way preserved the "possibility that states may use STEs to achieve broader public policy goals." (Hoekman and Trachtman, 2007 p. 3). The finding suggests that certain government policies, including STEs "may be appropriate responses to the exercise of market power by large multinational corporations in particular fields (ibid p. 18)." The fact that this approach has the dual outcome of preserving significant global market share for Canadian farmers while simultaneously sheltering producers from unstable international wheat prices is of no legal consequence. It is smart public policy, not anticompetitive behaviour. This panel will most likely be a significant ruling in the future for China, who uses a number of export STEs.

\section{The Future of the Canadian Wheat Board}

The American response to competitive pressure on the agriculture front has been a multi-pronged attack on the Canadian Wheat Board that includes domestic trade challenges, WTO dispute 
settlement, and continued pressure on Canadian agricultural industries at the WTO. In the larger scheme of things, this panel decision may be significant for the global regulation of export STEs (Trachtman and Hoekman, 2007, p. 12), but in the North American context, the ruling will likely have little impact on Canada/US trade relations in the agriculture sector.

This realist position on agricultural trade friction raises the question of whether some sort of compromise is possible within the industry. Young (2000) argues that American and Canadian agricultural producers may want to consider the possibility of forming binational 'commodity groups' that allow them to exploit a basic compatibility of interests. She suggests that resolution of trade friction in Canada-US agriculture disputes can be facilitated by an assessment of cooperative and competitive interests and 'rethinking the role of national commodity groups' (p. 33). This is not likely to produce a desirable outcome because Canada is the largest trade competitor with the US in important staples sectors, from softwood, to beef cattle to hard red spring wheat. In this case in particular, the fact that the CWB is a strategic competitor may be as much the issue as is how it organizes its commercial undertaking. WTO litigation has become a part of international competition strategies - especially in trade relationships that exhibit heterogeneous models for domestic commercial regulation and divergent policy goals for the outcome of international competition.

The divergent trajectories of Canadian and American commercial regulation are starkly seen in this case. In order to further illustrate American attitudes towards state trading, Annand (2000) compares the GATT's and the US Government Accountability Office's definition of STEs. The working definition of STEs from the Understanding on the Interpretation of Article XVII of GATT 1994 defines STEs as “Governmental and nongovernmental enterprises, including marketing boards, which have been granted exclusive or special rights or privileges, including statutory or constitutional powers, in the exercise of which they influence through their purchases or sales the level or direction of imports or exports.” The definition from a 1996 GAO report defines STEs as "enterprises that are authorized to engage in trade and are owned, sanctioned, or otherwise supported by the government” (US GAO, 1996) The key difference is that the GATT definition focuses on the impact of STEs on trade while the GAO definition focuses on their relationship to government, that is, the fact that they are not private actors.

This definitional difference goes to the heart of the unfair trade complaint. In the American institutional context, STEs are perceived to engage in unfair trade because they are at least marginally dependent upon their governments as the source of monopoly/monopsony rights, and therefore not always subject to the discipline of the market. Their buying and selling may be guided by factors other than market discipline. Underlying this argument, is the premise that international trade can only be fair if all countries have similar kinds of domestic policies $-\mathrm{a}$ level playing field depends upon everyone playing the same game with the same deck of cards.

This cognitive dissonance is should be considered in the context of two prominent features of North American agriculture trade. First, national support for agricultural producers has been steadily declining over the past twenty years and farmers in both countries have had to manage that structural adjustment process. Second, farmers in Canada and the US respond to the pressures of increased intrasectoral competition in ways that are compatible with historical modes of agricultural support in their respective national jurisdictions - namely export subsidies and trade litigation. Figure 1 below shows the most commonly used measure used to compare agriculture support amongst developed countries. 
Figure 1: The Apparent Gap between American and Canadian Support for Agricultural Producers: OECD Producer Support Estimates, 1986 - 2006 (in millions USD)

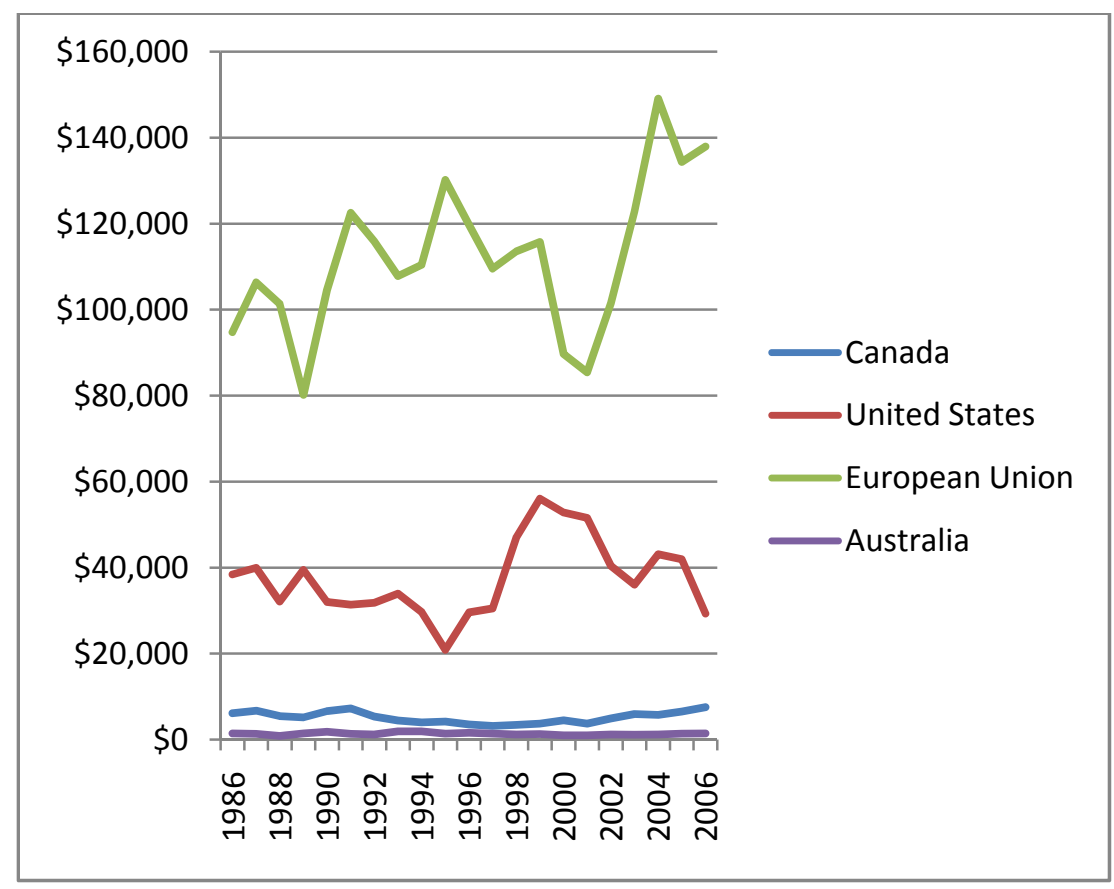

Source: OECD Statistical Database

The OECD’s Producer Support Estimates are an indicator of the annual value of "gross transfers from consumers and taxpayers to support agricultural producers, measured at farm gate level.” The PSE measures transfers to farmers from policies designed to maintain domestic prices, provide payments to farmers and support farmers through lower production input costs (OECD, 2007, p. 6). In sheer dollar amounts, the US outspends Canada in supporting agricultural producers according to the OECD. Producer support estimates measure show a significant amount of both direct and indirect state support. When using the most commonly accepted measure of producer support, Canada's policies seem to offer less support to producers, and therefore are less trade distorting.

However, the comparison of Canadian and US producer support obscures a more complex story. When producer and consumer support are factored together, Canada and the US exhibit a steady trend towards lower levels of agricultural support as a percentage of GDP (see Figure 2 below). Total Support Estimates measure "value of all gross transfers from taxpayers and consumers arising from policy measures which support agriculture” (OECD, 2007 p. 14). Total support for agriculture has declined significantly over the past twenty years. Farmers in both countries are dealing with long term structural adjustment in their agriculture sectors. Notably, the gap has narrowed considerably from levels of total support offered in the mid 1980s, when Canada's arrangements offered considerably more support to farmers than did the US. 
Figure 2: Narrowing the Gap in Agricultural Support in North America: OECD Total Support Estimates, 1986-2006 (as a \% of GDP)

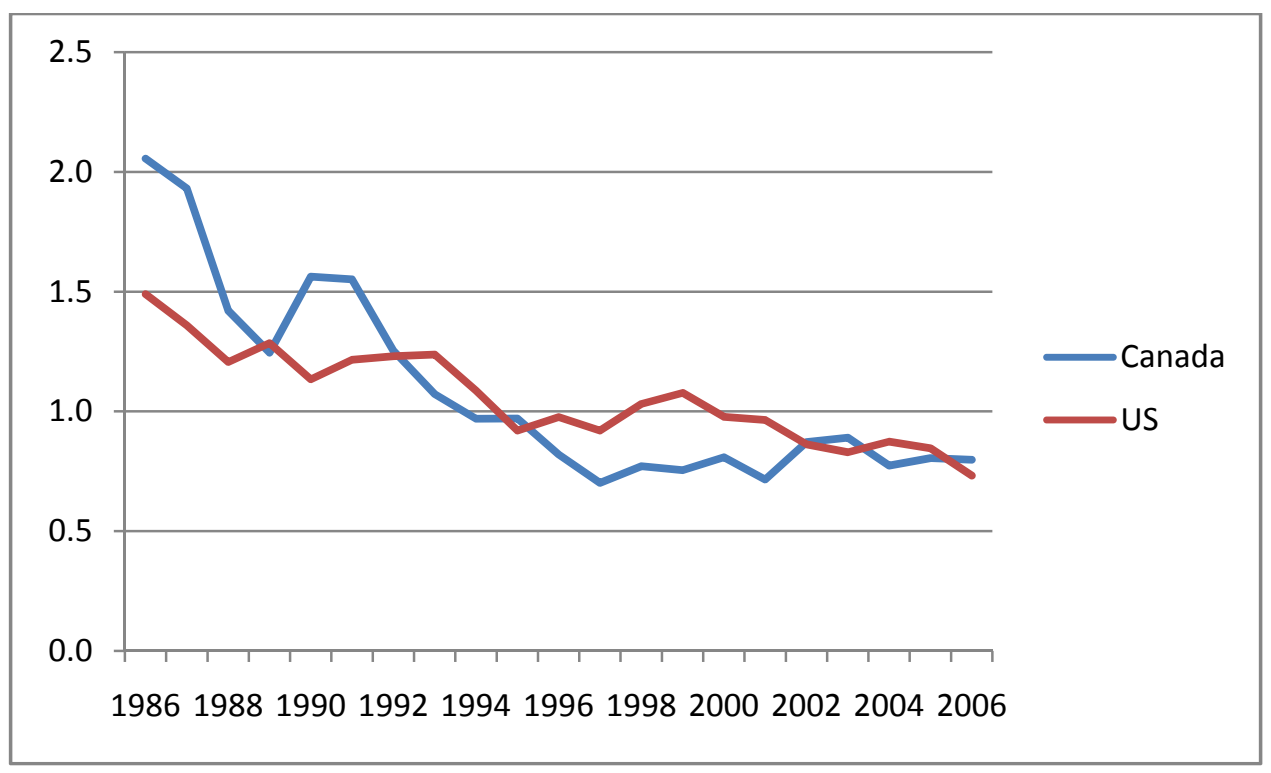

Source: OECD Statistical Database

Marketing boards have been very successful in the postwar era, and continue to be useful for a number of policy objectives. Given Canada's historical industrial development trajectory, which has moved from centralized public ownership to decentralization over the past two decades, The CWB may appear to be something of an anachronism. What then is the future of the CWB? Moving to an export model that more closely resembles the wheat industry in the US will not guarantee better relations with American wheat producers. Bearing this in mind, the federal government must carefully consider the implications of removing programs that provide security for domestic producers - especially because of aggressively protectionist sentiment in the American agriculture sector.

\section{Conclusion}

This paper does not take a position on whether the dismantling of the CWB will benefit or harm Canadian farmers. Rather, it suggests that economic decisions made in this area must consider all the relative merits and demerits of the Canadian competitive model for the export and sale of wheat. The Canadian model is weighted in favour of price security and predictability. The American alternative is weighted in favour of freer competition amongst producers and a greater role for corporate agribusiness in the marketing and sale of hard red spring wheat.

The ambiguity of GATT Article XVII places STEs in a difficult position vis-a-vis charges of unfair competition. After World War II, the GATT's framers were reluctant to disallow the single most important tool for social protection. Annand (2000) estimates that in the decades immediately following the Second World War, STEs accounted for approximately 25\% of world trade, with about $90 \%$ of the world's wheat exports coming under the influence of state traders. STEs are perhaps the most prominent symbol of agricultural protectionism, even as they 
have proven to be one of the most prudent ways to manage the social costs of trade liberalization. Analysis of Canada-Wheat shows the reasoning by which the panel was unwilling to agree with an expanded interpretation of non-discrimination - as operating under a single intellectual model of open markets - argued for by the US. The CWB was affirmed as a non-discriminatory mode of wheat export, even as a number of explicitly protectionist measures were disallowed by the WTO.

STEs are a significant feature of the post-war compromise with embedded liberalism. As such, the CWB is deeply rooted in Canada's historical trajectory of industrial development. I would like to put forward the hypothesis that the drive to dismantle the Wheat Board is part of the same developmental trajectory, and comparative examples of Canadian structural adjustment can be seen in the privatization of CN Rail and Petro Canada. Nevertheless, moving to a decentralized model for the marketing of Western Canadian wheat will not necessarily lessen trade friction as long as Western Canadian farmers are in direct competition with their American counterparts. 
Annex: US Trade Challenges to Canadian Wheat Exports, 1990 - 2006

\begin{tabular}{|c|c|c|}
\hline Investigation & Date Completed & Final Determination \\
\hline $\begin{array}{c}\text { USITC Investigation (under } \\
\text { Section } 332 \text { of the Tariff Act of } \\
1930\end{array}$ & Jun-90 & $\begin{array}{l}\text { Canadian wheat sold in the US at or above market prices } \\
\text { - no evidence of dumping }\end{array}$ \\
\hline $\begin{array}{l}\text { USGAO Review of the } \\
\text { CWB/AWB }\end{array}$ & Jun-92 & No evidence of unfair trade practices \\
\hline Canada-US Trade Agreement & Feb-93 & Panel ruling In favour of Canada \\
\hline $\begin{array}{l}\text { USITC Investigation (under } \\
\text { Section } 22 \text { of the Agricultural } \\
\text { Adjustment Act of } 1930\end{array}$ & Jul-94 & Negotiated cap on exports to the US for 1994-95 \\
\hline Joint Commission on Grains & Oct-95 & Recommendations to improve trade in both directions \\
\hline $\begin{array}{l}\text { US GAO (ability of STEs to } \\
\text { distort trade) }\end{array}$ & Jun-96 & $\begin{array}{l}\text { No evidence that the CWB violates any existing } \\
\text { agreements }\end{array}$ \\
\hline $\begin{array}{l}\text { US GAO (Canadian wheat } \\
\text { issues) }\end{array}$ & Nov-98 & No solid conclusions \\
\hline $\begin{array}{l}\text { US DOC (Countervailing duty } \\
\text { on live cattle from Canada) }\end{array}$ & Oct-99 & $\begin{array}{l}\text { No evidence that the CWB provides a subsidy to cattle } \\
\text { producers }\end{array}$ \\
\hline $\begin{array}{c}\text { USITC Investigation (under } \\
\text { Section } 332 \text { of the Tariff Act of } \\
1930\end{array}$ & Nov-01 & $\begin{array}{l}\text { Canadian wheat sold at or above US prices in all but one } \\
\text { of } 60 \text { months examined }\end{array}$ \\
\hline $\begin{array}{l}\text { USTR (Section } 301 \\
\text { investigtion) }\end{array}$ & Feb-02 & $\begin{array}{l}\text { No justification for imposing entry barriers to Canadian } \\
\text { wheat }\end{array}$ \\
\hline $\begin{array}{c}\text { US DOC / US ITC \& NAFTA } \\
\text { on appeal }\end{array}$ & $\begin{array}{l}\text { Aug } 2003 \text { - June } \\
2005\end{array}$ & $\begin{array}{l}\text { Duties imposed on Canadian Wheat by US DOC - lifted } \\
\text { in } 2006 \text { after successful NAFTA appeal }\end{array}$ \\
\hline US DOC / US ITC / US CIT & \begin{tabular}{|l|} 
August 2003 - July \\
2004
\end{tabular} & $\begin{array}{l}\text { Duties imposed on Canadian Wheat by US DOC, duties } \\
\text { revoked by US ITC, appeal dismissed by US CIT }\end{array}$ \\
\hline $\begin{array}{c}\text { US DOC / US ITC / US CIT \& } \\
\text { NAFTA on appeal }\end{array}$ & \begin{tabular}{|c|} 
August 2003 - June \\
2005
\end{tabular} & $\begin{array}{c}\text { Duties imposed on Canadian wheat by US DOC, US ITC } \\
\text { split on injury, decision defaults to petitioner - lifted in } \\
2006 \text { after successful NAFTA appeal }\end{array}$ \\
\hline $\begin{array}{c}\text { WTO panel and appeal (DS276 } \\
\text { Canada: Measures relating to } \\
\text { exports of wheat and treatment } \\
\text { of Imported Grain) }\end{array}$ & Aug-04 & $\begin{array}{l}\text { US argument that the CWB violates GATT Article XVII } \\
\text { dismissed at panel and appeal. Finding that three other } \\
\text { Canadian measures violate GATT Article III }\end{array}$ \\
\hline
\end{tabular}


"2006-2007 Statistical Tables." Canadian Wheat Board, www.cwb.ca/public/en/library/publications/.

"A History of U.S. Trade Challenges." Canadian Wheat Board. www.cwb.ca/public/en/hot/trade/popups/trade_history.jsp.

Abbott, P. C., and P.K.S. Kallio. "Implications of Game Theory for International Agriculture Trade." American Journal of Agricultural Economics 78 (1996): 738-44.

Annand, Mel. "State Trading Enterprises: A Canadian Perspective." The Estey Centre Journal of International Law and Trade Policy 1, no. 1 (2000): 36-50.

Barnes, Angela. "Grains Push Commodity Index Higher." Globe and Mail, October 252007.

"Canada - Measures Relating to Exports of Wheat and Treatment of Imported Grain." WT/DS276/R, WT/DS276/AB/R. Geneva: World Trade Organization, 2004.

Carter, Colin A., and R.M.A Loyns. "The Economics of Single Desk Selling of Western Canadian Grain." (1996), http://www1.agric.gov.ab.ca/\$department/deptdocs.nsf/all/agc2248.

Clarkson, Stephen. "The Multi-Level State: Canada in the Semi-Periphery of Both Continentalism and Globalization." Review of International Political Economy 8, no. 3 (2001): 501-27.

Cross, Philip. "The New Underground Economy of Subsoil Resources: No Longer Hewers of Wood and Drawers of Water." Canadian Economic Observer (2007).

Davey, William J. "Article XVII GATT: An Overview." In State Trading in the Twenty-First Century, edited by Thomas Cottier and Petros C. Mavroidis. Ann Arbor: University of Michigan Press, 2001.

"Dispute Settlement Commentary - WT/DS276/R." In Worldtradelaw.net Dispute Settlement Commentary. Wellington, FL: Worldtradelaw.net LLC, 2004.

Furtan, Hartley W. "Transformative Change in Agriculture: The Canadian Wheat Board." The Estey Centre Journal of International Law and Trade Policy 6, no. 2 (2005): 95-107.

Gagne, Gilbert. "The Canada-Us Softwood Lumber Dispute: A Test Case for the Development of International Rules." International Journal 58, no. 3 (2003).

Goodloe, Carol. "The Canadian Wheat Board: Government Guarantees and Hidden Subsidies?" The Estey Centre Journal of International Law and Trade Policy 5, no. 2 (2004): 102-22. 
Goodwin, Barry K., and Vincent H. Smith. "Price Discrimination Ininternational Wheat Markets / a Report Prepared Forthe Wheat Export Trade Education Committee (Wetec)." 30, 1995.

Herman, Lawrence L. "American Corn and Canadian Trade Actions: One Step Forward, Two Steps Back." C.D. Howe Institute 2007.

Hoekman, Bernard and Joel Trachtman. "Canada-Wheat: Discrimination, Non-Commercial Considerations, and State Trading Enterprises." The World Bank / Development Research Group / Trade Team, 2007.

Keohane, Robert O. After Hegemony: Cooperation and Discord in the World Political Economy. Princeton, N.J.: Princeton University Press, 1984.

Lambert, Steve. "Ottawa Loses Battle over Wheat Board." The Globe and Mail, February 27 2008.

Migie, Howard, Mike Bast, Brenda Brindle, Rob Davies, John Groenewegen, Bruce Johnson, and Paul Orsak. "Marketing Choice - the Way Forward / Report of Technical Task Force on Implementing Marketing Choice for Wheat and Barley." (2006), http://www.agr.gc.ca/cb/ip/pdf/final_251006_e.pdf.

Petersmann, Ernst-Ulrich. "Gatt Law and State Trading Enterprises: Critical Evaluation of Article Xvii and Proposals for Reform." In State Trading in the Twenty-First Century, edited by Thomas Cottier and Petros C. Mavroidis. Ann Arbor: University of Michigan Press, 1998.

Pick, D. H., and C. A. Carter. "Pricing to Market with Transactions Denominated in a Common Currency." American Journal of Agricultural Economics 76 (1994): 55-60.

"The Regulation of State Trading under the WTO System." Geneva: World Trade Organization (2007), www.wto.org/english/tratop_e/statra_e/statrad.htm.

"Report (2007) of the Working Party on State Trading Enterprises." Geneva: World Trade Organization, 2007.

Rude, James. "Canadian Agriculture and the Doha Development Agenda: The Challenges." The Estey Centre Journal of International Law and Trade Policy 7, no. 1 (2006): 32-48.

—_. "European Union Grain Export Practices: Do They Constitute a State Trading Enterprise?" The Estey Centre Journal of International Law and Trade Policy 3, no. 2 (2002): 176-89.

Ruggie, John Gerard. "International Regimes, Transactions, and Change: Embedded Liberalism in the Postwar Economic Order." International Organization 36, no. 2 (1982): 379-415. 
"Stand up for Canada: Conservative Party of Canada Federal Election Platform." http://www.conservative.ca/media/20060113-Platform.pdf.

State Trading Enterprises in Agriculture. Paris: Organization for Economic Cooperation and Development, 2001.

Trebilcock, Michael J., and Robert Howse. The Regulation of International Trade. 2nd ed. London: Routledge, 1999.

United States Government Accountability Office. "Canada, Australia and New Zealand: Potential Ability of State Trading Enterprises to Distort Trade." GAO/NSIAD-96-94, Washington D.C. 1996.

Veeman, M., M. Fulton, and B. Larue. "International Trade in Agricultural and Food Products: The Role of State Trading Enterprises, Report for Agriculture and Agri-Food Canada." Ottawa: Agriculture Canada, 1999.

"Wheat Benchmarks Report-Establishing Value of a Monopoly." Canadian Wheat Board, http://www.cwb.ca/public/en/library/publications/popups/farmers_wheatbenchmark.jsp.

Yildirim, Tulay, Andrew Schmitz, and Hartley W. Furtan, eds. World Agricultural Trade: Westview Press, 1998.

Young, Linda M. "U.S. - Canadian Agricultural Trade Conflicts: Time for a New Paradigm." The Estey Centre Journal of International Law and Trade Policy 1, no. 1 (2000): 22-35.

Zysman, John. "How Institutions Create Historically Rooted Trajectories of Growth." Industrial and Corporate Change 3, no. 1 (1994). 